\title{
Are local wind power resources well estimated?
}

\section{Lundtang Petersen, Erik; Troen, lb; Ejsing Jørgensen, Hans; Mann, Jakob}

\section{Published in:}

Environmental Research Letters

Link to article, DOI:

10.1088/1748-9326/8/1/011005

Publication date:

2013

Document Version

Publisher's PDF, also known as Version of record

Link back to DTU Orbit

\section{Citation (APA):}

Lundtang Petersen, E., Troen, I., Ejsing Jørgensen, H., \& Mann, J. (2013). Are local wind power resources well estimated? Environmental Research Letters, 8, 011005. https://doi.org/10.1088/1748-9326/8/1/011005

\section{General rights}

Copyright and moral rights for the publications made accessible in the public portal are retained by the authors and/or other copyright owners and it is a condition of accessing publications that users recognise and abide by the legal requirements associated with these rights.

- Users may download and print one copy of any publication from the public portal for the purpose of private study or research.

- You may not further distribute the material or use it for any profit-making activity or commercial gain

- You may freely distribute the URL identifying the publication in the public portal

If you believe that this document breaches copyright please contact us providing details, and we will remove access to the work immediately and investigate your claim 
Are local wind power resources well estimated?

This article has been downloaded from IOPscience. Please scroll down to see the full text article.

2013 Environ. Res. Lett. 8011005

(http://iopscience.iop.org/1748-9326/8/1/011005)

View the table of contents for this issue, or go to the journal homepage for more

Download details:

IP Address: 130.226.56.2

The article was downloaded on 30/05/2013 at 13:30

Please note that terms and conditions apply. 


\section{PERSPECTIVE}

\section{Are local wind power resources well estimated?}

Erik Lundtang Petersen, Ib Troen, Hans E Jørgensen and Jakob Mann Wind Energy Department, Technical University of Denmark, Ris $\phi$ Campus, Frederiksborgvej 399, Roskilde, Denmark jmsq@dtu.dk
Planning and financing of wind power installations require very importantly accurate resource estimation in addition to a number of other considerations relating to environment and economy. Furthermore, individual wind energy installations cannot in general be seen in isolation.

It is well known that the spacing of turbines in wind farms is critical for maximum power production. It is also well established that the collective effect of wind turbines in large wind farms or of several wind farms can limit the wind power extraction downwind. This has been documented by many years of production statistics. For the very large, regional sized wind farms, a number of numerical studies have pointed to additional adverse changes to the regional wind climate, most recently by the detailed studies of Adams and Keith [1]. They show that the geophysical limit to wind power production is likely to be lower than previously estimated. Although this problem is of far future concern, it has to be considered seriously. In their paper they estimate that a wind farm larger than $100 \mathrm{~km}^{2}$ is limited to about $1 \mathrm{~W} \mathrm{~m}^{-2}$. However, a $20 \mathrm{~km}^{2}$ off shore farm, Horns $\operatorname{Rev} 1$, has in the last five years produced $3.98 \mathrm{~W} \mathrm{~m}^{-2}$ [5]. In that light it is highly unlikely that the effects pointed out by [1] will pose any immediate threat to wind energy in coming decades.

Today a number of well-established mesoscale and microscale models exist for estimating wind resources and design parameters and in many cases they work well. This is especially true if good local data are available for calibrating the models or for their validation.

The wind energy industry is still troubled by many projects showing considerable negative discrepancies between calculated and actually experienced production numbers and operating conditions. Therefore it has been decided on a European Union level to launch a project, 'The New European Wind Atlas', aiming at reducing overall uncertainties in determining wind conditions.

The project is structured around three areas of work, to be implemented in parallel.

- Creation and publication of a European wind atlas in electronic form [2], which will include the underlying data and a new EU wind climate database which will as a minimum include: wind resources and their associated uncertainty; extreme wind and uncertainty; turbulence characteristics; adverse weather conditions such as heavy icing, electrical storms and so on together with the probability of occurrence; the level of predictability for short-term forecasting and assessment of uncertainties; guidelines and best practices for the use of data especially for micro-siting.

- Development of dynamical downscaling methodologies and open-source models validated through measurement campaigns, to enable the provision of accurate wind resource and external wind load climatology and short-term prediction at high spatial resolution and covering Europe. The developed 
downscaling methodologies and models will be fully documented and made publicly available and will be used to produce overview maps of wind resources and other relevant data at several heights and at high horizontal resolution.

- Measurement campaigns to validate the model chain used in the wind atlas. At least five coordinated measurement campaigns will be undertaken and will cover complex terrains (mountains and forests), offshore, large changes in surface characteristics (roughness change) and cold climates.

One of the great challenges to the project is the application of mesoscale models for wind resource calculation, which is by no means a simple matter [3]. The project will use global reanalysis data as boundary conditions. These datasets, which are time series of the large-scale meteorological situation covering decades, have been created by assimilation of measurement data from around the globe in a dynamical consistent fashion using large-scale numerical models. For wind energy, the application of the reanalysis datasets is as a long record of the large-scale wind conditions. The large-scale reanalyses are performed in only a few global weather prediction centres using models that have been developed over many years, and which are still being developed and validated and are being used in operational services. Mesoscale models are more diverse, but nowadays quite a number have a proven track record in applications such as regional weather prediction and also wind resource assessment. There are still some issues, and use of model results without proper validation may lead to gross errors. For resource assessment it is necessary to include direct validation with in situ observed wind data over sufficiently long periods. In doing so, however, the mesoscale model output must be downscaled using some microscale physical or empirical/statistical model. That downscaling process is not straightforward, and the microscale models themselves tend to disagree in some terrain types as shown by recent blind tests [4]. All these 'technical' details and choices, not to mention the model formulation itself, the numerical schemes used, and the effective spatial and temporal resolution, can have a significant impact on the results. These problems, as well as the problem of how uncertainties are propagated through the model chain to the calculated wind resources, are central in the work with the New European Wind Atlas. The work of [1] shows that when wind energy has been implemented on a very massive scale, it will affect the power production from entire regions and that has to be taken into account.

\section{References}

[1] Adams A S and Keith D W 2013 Are global wind power resource estimates overstated? Environ. Res. Lett. 8015021

[2] 2011 A New EU Wind Energy Atlas: Proposal for an ERANET+ Project (Produced by the TPWind Secretariat) Nov.

[3] Petersen E L and Troen I 2012 Wind conditions and resource assessment WIREs Energy Environ. 1 206-17

[4] Bechmann A, Sørensen N N, Berg J, Mann J and Rethore P-E 2011 The Bolund experiment, part II: blind comparison of microscale flow models Boundary-Layer Meteorol. 141 245-71

[5] www.lorc.dk/offshore-wind-farms-map/horns-rev-1

www.ens.dk 